\title{
Internet Usage Habits and Cyberbullying Related Opinions of Secondary School Students
}

\author{
Şener Şentürk ${ }^{1, *}$, Seher Bayat ${ }^{2}$ \\ ${ }^{1}$ Ministry of National Education, Turkey \\ ${ }^{2}$ Faculty of Education, Ordu University, Turkey
}

Copyright $\bigcirc 2016$ by authors, all rights reserved. Authors agree that this article remains permanently open access under the terms of the Creative Commons Attribution License 4.0 International License

\begin{abstract}
The purpose of this research is to examine the internet usage habits of secondary school students and their awareness of cyberbullying in terms of different variables. Of the probabilistic sampling methods, research sampling identified by stratified sampling method has been formed by 559 students from two branches (56 branches in total) selected with simple random sampling method (For example; 5/A and 5/C) at each grade level (5th, 6th, 7th and 8th grades) from 7 schools in Merzifon. Data in the research have been obtained by the form related to the personal information and "Cyberbullying Scale". Due to the absence of normal distribution of data, the frequency tables in the analysis of data, Mann-Whitney $\mathrm{U}$ and Kruskal-Wallis $\mathrm{H}$ tests were used. According to the results of the research, it has been detected that the cyberbullying related awareness of the secondary school students is low ( $\bar{x}=20.24$ out of 42 ); there is no significant difference in terms of gender, having personal computer and mobile phone and there are some significant differences in terms of the variables such as the type of school and class level. While the internet use purposes of the students is mostly making research and doing homework, it is seen that using social network such as Facebook is common among the students despite being illegal due to their ages.
\end{abstract}

Keywords Cyberbullying, Internet Usage, Secondary School Students

\section{Introduction}

Computer technology, one of the most important inventions of our time, has the role of an indispensable source and a rapid tool on the subjects such as accessing information thanks to the internet, sharing information, communicating, enjoying time. This advancement in technology has affected many areas from games to education types, from communication to socialization and has made it compulsory to redefine some definitions [1]. While bullying, one of these notions, is defined as physical or psychological violence deliberately applied to a person who cannot defend himself by one or more people who are stronger, as a result of misuse of the technology which makes our lives easier, in the real world bullying way has changed its form and this has led to the emergence of the concept of cyber-bullying.

Belsey [2], the first person to use the cyber-bullying in terminology, defines it as "the use of information and communication technologies such as e-mail, cell phone and pager text messages, instant messaging, defamatory personal websites, and defamatory online personal polling websites, to support deliberate, repeated, and hostile behaviour by an individual or group, that is intended to harm others".

Ayas \& Horzum [3] defines cyber-bullying as the usage of technologies such as internet and mobile phones in order to harm people; whereas, Bayram \& Saylı [4] explains it as insulting others deliberately, humiliating, exclusing, threating, exposure or disturbing them via use of communication tools in a virtual environment.

Cyber-bullying, which is also called as virtual bullying, digital bullying, internet bullying, harassment through internet, psychological attack, can be defined - in the most general term- as bully behaviors including tendencies such as the use of e- mail, mobile phone, sending text messages, personal website buckling and damage to information, harassment, slanders, imitating people to share private information, removing individuals out of the groups deliberately, insulting and threating others $[5,6,7,8,9]$.

In cyber-bullying which doesn't need physical power, only virtual capability can make a person bully others anywhere and anytime as long as there are communication devices such as telephone and internet $[10,11]$, on the other hand, being able to hiding identity makes it possible to continue treating, intimidating, harming, insulting people without hesitation in the virtual world $[12,13]$. However, these behaviors' lead psychological and physical discomfort on those who bullies and victims. While victims experience irritation, frustration, sadness , anger, hatred, humiliation and a sense of uneasiness $[14,15]$; tyrants tend to violence, delinquency and substance use and show less academic success $[16,17]$. 
The meeting of the perpetrator and the victim of cyberbullying which doesn't contain face to face violence can result in irretrievable results in the real life [18]. Rarely experienced by the adults, this situation can cause serious problems among the students especially in peer groups who use the internet unconsciously. Because it is a known fact that almost half of the victims $(48 \%)$ know the tyrants in cyberbullying events among students [19]. Although cyberbullies are known, one of the main reasons of cyberbullying is acceptance to the peer groups which carries great importance for the students [20]. With the anxiety of being rejected, victims adopting wrong models don't ask for help with the fear of exclusivity and continue behaving without thinking of the possible results and after a while they start cyberbullying others [21].

Reaching up to $30 \%$, cyberbullying rates in Turkey [22], has made it clear that students in lower grades are exposed to cyberbullying more than higher grades [23]. Furthermore, it has been stated that $85 \%$ of the active internet users are under 13 and they use facebook showing their ages higher than their real ages though it is illegal, and $42 \%$ of these students' information is open to general usage [24]. In a study in which bullying rates of secondary and high school students are investigated, it is seen that cyberbullying rate at secondary school ( $8^{\text {th }}$ grade) is $12 \%$ while it is $9 \%$ at high school (11 ${ }^{\text {th }}$ grade) [25]; on the other hand, it is stated that cyberbullying awareness gets higher as grades get higher. From this point of view, it can be asserted that cyberbullying awareness rises as grades rise; therefore, secondary school students who begin using internet actively are in the risky group [1].

National Education Ministry has taken important steps towards becoming a knowledge society by uniting the education system with technology through Fatih Project which was launched throughout Turkey and it installed smart boards into the classrooms, delivered tablets to students and teachers for free, established Education Information Network (EBA) composed of e-content programs, e- documents and e- courses. However, since this situation which aims students' active usage of internet and generalization of internet-enabled learning among students hasn't been supported by the education of students, parents and teachers' awareness education for this subject, it has created many kinds of online risks from cyberbullying to pornography among peer groups. Foreseeing this situation beforehand, National education ministry developed the school subject Media Literacy which explains the potential harm of using computers to human health but the content has been introduced superficially. In 2009, even though the Ministry of Education prepared Tips for Safe Internet Use project in cooperation with Ministry of Transportation and Information Technologies and Communications Authority, and Ministry of Development prepared Information Society Strategy of Renewal project and it was adopted as a strategic goal for generalization of information and communication technologies (ICT) and studies have been initiated relating to this subject, $30 \%$ of cyber-bullying rate indicates that children, parents and educators do not have enough knowledge on the subject.

For this reason, it is essential to define the internet usage habits of the students and determine the relationship of these habits related to cyberbullying; detect the students who are in possible risky groups, and ensure them to gain awareness of the issue. Regarding this purpose, this study aims to identify the internet usage habits of the students and their awareness level of cyberbullying. Moreover, it is expected that this study will be able to contribute to the literature with the identification of secondary school students'

\section{Methods}

In this research, it has been aimed to describe the secondary school students' internet usage habits and their sensitivity related to cyberbullying. Scanning model used in the research is a research approach aiming to describe a situation existed in the past and at present as it is there [25].

The universe of the research consists of 1182 students studying in Merzifon town of Amasya province in the 2015-2016 academic years. Due to being layers in the universe of the research (class-branch), of contingent sampling methods stratified sampling method was used in terms of representing the universe [26]. Naturally, in the universe that has been divided into layers such as school, class and branches, two branches (For example 5/A and 5/C) selected at each school and class level (5-6-7-8) with simple random sampling were determined. In the sample, which includes all of the existing secondary schools, the number of schools is 7, the number of branches is 56 and the number of students is 559 .

In the research conducted to define internet usage habits and their sensitivity towards cyberbullying, the data have been obtained with the information relating personal information and cyber bullying scale. Cyber bullying scale used in the research has been developed by Tanrikulu, Kinay \& Aricak [27] and it consists of 14 items. The lowest score to be obtained from the scale is 14 and the highest score is 42 and the increase in the score means the increase in the sensitivity. Internal consistency coefficients of the one-factor scale were found to be .83 to .90 and two semi-test reliability coefficients were found to be .75 to .84 and accordingly, it was accepted that the scale is reliable. For this research, Cronbach Alpha coefficient has been detected to be 0,826 .

The analysis of the data has been made with SPSS for Windows 21 statistics program. As a result of Kolmogrov Simirrnov test, the distribution of the data was found to be not normal. For this reason, Mann- Whitney U and Kruskal Wallis Tests were used in the analysis of data.

\section{Findings}

In this section, the data were entered into SPSS package program and it was reached to the frequency and percentage values findings of the items. 
Table 1. Demographic Features

\begin{tabular}{|c|c|c|c|}
\hline \multicolumn{2}{|c|}{ Demographic Features } & $\mathrm{f}$ & $\%$ \\
\hline \multirow{2}{*}{ Gender } & Female & 311 & 55.64 \\
\hline & Male & 248 & 44.36 \\
\hline \multirow{7}{*}{ School Type } & Secondary School-1 & 79 & 14.13 \\
\hline & Secondary School-2 & 62 & 11.09 \\
\hline & Secondary School-3 & 90 & 16.10 \\
\hline & Secondary School-4 & 78 & 13.95 \\
\hline & Secondary School-5 & 103 & 18.43 \\
\hline & Secondary School-6 & 67 & 11.99 \\
\hline & Secondary School-7 & 80 & 14.31 \\
\hline \multirow{4}{*}{ Class } & 5th Grade & 201 & 35.96 \\
\hline & 6th Grade & 149 & 26.65 \\
\hline & 7th Grade & 109 & 19.50 \\
\hline & 8th Grade & 100 & 17.89 \\
\hline \multirow{2}{*}{ Personal Pc } & Yes & 365 & 65.30 \\
\hline & No & 188 & 33.63 \\
\hline \multirow{2}{*}{ Mobile Phone } & Yes & 285 & 50.98 \\
\hline & No & 270 & 48.30 \\
\hline \multirow{2}{*}{ Facebook Account } & Yes & 332 & 59.39 \\
\hline & No & 222 & 39.71 \\
\hline \multirow{2}{*}{ TwitterAccount } & Yes & 83 & 14.85 \\
\hline & No & 476 & 85.15 \\
\hline \multirow{4}{*}{ Internet use frequency } & Continuous & 66 & 11.81 \\
\hline & A few hours in a day & 172 & 30.77 \\
\hline & A few hours in a week & 241 & 43.11 \\
\hline & A few hours in a month & 79 & 14.13 \\
\hline \multirow{4}{*}{ Internet use purpose } & Information Purpose (Research-homework) & 325 & 58.14 \\
\hline & Social Purpose (Communication-chat) & 80 & 14.31 \\
\hline & Commercial Purpose (Shopping) & 12 & 2.15 \\
\hline & Fun (Game- film etc.) & 141 & 25.22 \\
\hline
\end{tabular}

It has been seen that 311 participants of research are female and 248 of them are male, 201 students are in 5th grade, 149 of them are in 6th grade, 109 of them are in 7th grade and 100 of them in the 8 th grade and 365 students have personal computer and 285 of them have mobile phones; 332 students use Facebook and 83 students use twitter.

The general evaluation results of the students that has been made by using descriptive statistics related to cyberbullying are presented in 2 .

Table 2. Cyberbullying Sensitivity

\begin{tabular}{|c|c|c|c|}
\hline & $\mathrm{n}$ & $\bar{x}$ & Standard Deviation \\
\hline Cyberbullying Sensitivity & 559 & 20.24 & 5.58960 \\
\hline
\end{tabular}

According to Table 2, the sensitivity of the students related to Cyberbullying Scale is seen to be low with $\bar{x}=$ 20.24 out of 42 . In other words, it can be said that the secondary school students do not have sufficient knowledge and awareness about cyberbullying.

Mann-Whitney $U$ and Kruskal Wallis Test analysis results performed to detect whether the sensitivity of the students to Cyberbullying Scale varies depending on demographic features are given below.

Table 3. Cyberbullying Sensitivity According To Gender

\begin{tabular}{|c|c|c|c|c|c|}
\hline & $\mathrm{n}$ & $\bar{x}_{\text {sira }}$ & $\sum_{\text {sira }}$ & $\mathrm{U}$ & $\mathrm{p}$ \\
\hline Female & 311 & 286.59 & 89129 & 36515 & .278 \\
\hline Male & 248 & 271.74 & 67391 & & \\
\hline
\end{tabular}

According to Table 3, there is no significant difference between female and male students in terms of cyberbullying sensitivity. Although the mean of female students is seen to be more sensitive than the mean of made students, it can be interpreted that gender factor is not effective on cyberbullying sensitivity. 
Table 4. Kruskal Wallis Result According To School Type

\begin{tabular}{|c|c|c|c|c|c|}
\hline School Type & $\mathrm{n}$ & $\bar{x}$ & $\chi^{2}$ & $\mathrm{df}$ & $\mathrm{p}$ \\
\hline School-1 & 79 & 450.80 & 168.524 & 6 & .000 \\
\hline School-2 & 62 & 300.82 & & & \\
\hline School-3 & 90 & 299.04 & & & \\
\hline School-4 & 78 & 280.62 & & & \\
\hline School-5 & 103 & 184.34 & & & \\
\hline School-6 & 67 & 312.51 & & & \\
\hline School-7 & 80 & 169.11 & & & \\
\hline
\end{tabular}

According to Table 4, as a result of Kruskal Wallis-H performed to detect whether cyberbullying scale listing means show a significant difference according to the schools, a statistically significant difference has been found $(\chi 2=168.524 ; \quad \mathrm{df}=6 ; 05) . \quad$ Following this operation, complementary comparison has been made to define from which groups the significant difference detected after Kruskal Wallis-H was resulted from.

Table 5. Interschool Differences Complementary Comparison

\begin{tabular}{|c|c|c|c|c|c|}
\hline School code & TestStatistic & Std.TestError & Std.TestStatistic & Sig & Adj.Sig \\
\hline $7-5$ & 15.238 & 23.974 & 636 & .525 & 1.000 \\
\hline $7-4$ & 111.509 & 25.598 & 4.356 & .000 & $.000 *$ \\
\hline $7-3$ & 129.938 & 24.719 & 5.257 & .000 & $.000 *$ \\
\hline $7-2$ & 131.716 & 27.219 & 4.839 & .000 & $.000 *$ \\
\hline $7-6$ & 143.401 & 26.641 & 5.383 & .000 & $.000 *$ \\
\hline $7-1$ & 281.691 & 25.516 & 11.040 & .000 & $.000 *$ \\
\hline $5-4$ & 96.271 & 24.146 & 3.987 & .000 & $.000^{*}$ \\
\hline $5-3$ & 114.700 & 23.212 & 4.941 & .000 & $.000 *$ \\
\hline $5-2$ & 116.478 & 25.858 & 4.504 & .000 & $.000 *$ \\
\hline $5-6$ & -128.163 & 25.249 & -5.076 & .000 & $.000 *$ \\
\hline $5-1$ & 266.453 & 24.059 & 11.075 & .000 & $.000 *$ \\
\hline $4-3$ & 18.429 & 24.886 & .741 & .459 & 1.000 \\
\hline $4-2$ & 20.207 & 27.371 & .738 & .460 & 1.000 \\
\hline $4-6$ & -31.892 & 26.796 & -1.190 & .234 & 1.000 \\
\hline $4-1$ & 170.182 & 25.678 & 6.628 & .000 & $.000 *$ \\
\hline $3-2$ & 1.778 & 26.551 & .067 & .947 & 1.000 \\
\hline $3-6$ & -13.463 & 25.957 & .519 & .604 & 1.000 \\
\hline $3-1$ & 151.753 & 24.802 & 6.119 & .000 & $.000 *$ \\
\hline $2-6$ & -11.685 & 28.349 & -412 & .680 & 1.000 \\
\hline $2-1$ & 149.975 & 27.294 & 5.495 & .000 & $.000 *$ \\
\hline $6-1$ & 138.290 & 26.718 & 5.176 & .000 & $.000 *$ \\
\hline
\end{tabular}


According to Table 5, it is seen to be a significant difference between 7 (whatever the school name is) and 1, 2, $3,4,6$; between 5 and $1,2,3,4,6$; between $2,3,4,6$ and 1 . It is seen that the highest mean belongs to $1(\bar{x}=450.80)$ in terms of the means and the lowest sensitivity belongs to 7 $(\bar{x}=169.11)$.

Table 6. Kruskal Wallis Test Result According To Class Level

\begin{tabular}{|c|c|c|c|c|c|}
\hline Class Level & $\mathrm{n}$ & $\bar{x}$ & $\chi^{2}$ & $\mathrm{df}$ & $\mathrm{p}$ \\
\hline 5th Class & 201 & 246.14 & 16.253 & 3 & .001 \\
\hline 6th Class & 149 & 284.00 & & & \\
\hline 7th Class & 109 & 305.92 & & & \\
\hline 8th Class & 100 & 313.85 & & & \\
\hline
\end{tabular}

According to Table 6, as a result of Kruskal Wallis-H made to detect whether cyberbullying scale listing means show a significant difference according to the classes, a statistically significant difference was found $(\chi 2=16.253$; $\mathrm{df}=3 ; 05)$. Complementary comparison has been made to define from which groups the significant difference was resulted from.

Table 7. Interclass Differences Complementary Comparison

\begin{tabular}{|c|c|c|c|c|c|}
\hline $\begin{array}{c}\text { Class } \\
\text { Level }\end{array}$ & $\begin{array}{c}\text { Test } \\
\text { Statistic }\end{array}$ & $\begin{array}{c}\text { Std.Test } \\
\text { Error }\end{array}$ & $\begin{array}{c}\text { Std.Test } \\
\text { Statistic }\end{array}$ & Sig & Adj.Sig \\
\hline $5-6$ & -37.855 & 17.391 & -2.177 & .029 & .177 \\
\hline $5-7$ & -59.776 & 19.136 & -3.124 & .002 & $.011^{*}$ \\
\hline $5-8$ & -67.708 & 19.686 & -3.439 & .001 & $.003^{*}$ \\
\hline $6-7$ & -21.921 & 20.276 & -1.081 & .280 & 1.000 \\
\hline $6-8$ & -29.853 & 20.796 & -1.436 & .151 & .907 \\
\hline $7-8$ & -7.933 & 22.276 & -.356 & .722 & 1.000 \\
\hline
\end{tabular}

According to Table 7, it is seen to be a significant difference between 5 th classes and 7 th and 8 th Classes. It is seen that 8 th classes have the highest mean in terms of means $(\bar{x}=313.85)$ and 5 th classes have the lowest sensitivity $(\bar{x}=246.14)$. In this line, it can be said that the sensitivity of the 5 th classes.

Table 8. Mann-Whitney U Test Results According To Pc Usage

\begin{tabular}{|c|c|c|c|c|c|}
\hline & $\mathrm{n}$ & $\bar{x}_{\text {sira }}$ & $\sum_{\text {sira }}$ & $\mathrm{U}$ & $\mathrm{p}$ \\
\hline 1 & 365 & 259.39 & 94677.00 & 27882 & .000 \\
\hline 2 & 188 & 311.19 & 58504.00 & & \\
\hline
\end{tabular}

According to Table 8 , there is a significant difference in terms of pc use of the students. Accordingly, the students who have no personal computer have higher sensitivity to bullying $(\bar{x}=311.19)$.

Table 9. Personal mobile phone Mann-Whitney U test results

\begin{tabular}{|c|c|c|c|c|c|}
\hline & $\mathrm{n}$ & $\bar{x}_{\text {sira }}$ & $\sum_{\text {sira }}$ & $\mathrm{U}$ & $\mathrm{p}$ \\
\hline 1 & 285 & 275.41 & 78492.00 & 37737 & .695 \\
\hline 2 & 270 & 280.73 & 75798.00 & & \\
\hline
\end{tabular}

According to Table 9, there is no significant difference in terms of personal mobile phone use. Besides, the ones who do not use mobile phone are seen to have higher sensitivity level $(\bar{x}=280.73)$.

Table 10. Internet use frequency Kruskal Wallis Test result

\begin{tabular}{|c|c|c|c|c|c|}
\hline Use frequency & $\mathrm{n}$ & $\bar{x}$ & $\chi^{2}$ & $\mathrm{df}$ & $\mathrm{p}$ \\
\hline 1.Continuous & 66 & 295.54 & 12.729 & 3 & .005 \\
\hline 2.A few hours in a day & 172 & 294.56 & & & \\
\hline $\begin{array}{c}\text { 3.A few hours in a } \\
\text { week }\end{array}$ & 241 & 252.73 & & & \\
\hline $\begin{array}{c}\text { 4.Afew hours in a } \\
\text { month }\end{array}$ & 79 & 314.99 & & & \\
\hline
\end{tabular}

According to Table 10, as a result of Kruskal Wallis-H performed to detect whether cyberbullying scale listing means have a significant difference according to the use frequency, a statistically significant difference was found $(\chi 2=12.729 ; \quad \mathrm{df}=3 ; 05)$. Following this operation, complementary comparison has been made to define from which groups the significant difference detected after Kruskal Wallis-H was resulted from.

Table 11. Use Frequency Complementary Comparison

\begin{tabular}{|c|c|c|c|c|c|}
\hline $\begin{array}{c}\text { Use } \\
\text { frequency }\end{array}$ & $\begin{array}{c}\text { Test } \\
\text { Statistic }\end{array}$ & $\begin{array}{c}\text { Std.Test } \\
\text { Error }\end{array}$ & $\begin{array}{c}\text { Std.Test } \\
\text { Statistic }\end{array}$ & Sig & Adj.Sig \\
\hline $3-2$ & 41.888 & 16.057 & 2.609 & .009 & .091 \\
\hline $3-1$ & 42.834 & 22.349 & 1.917 & .055 & .553 \\
\hline $3-4$ & -62.304 & 20.856 & -2.987 & .003 & $.028^{*}$ \\
\hline $2-1$ & .946 & 23.293 & .041 & .968 & 1.000 \\
\hline $2-4$ & -20.415 & 21.864 & -934 & .350 & 1.000 \\
\hline $1-4$ & -19.470 & 26.827 & -.726 & .468 & 1.000 \\
\hline
\end{tabular}

According to Table 11, it is seen that there is a significant difference between the ones using internet for a few hours in a week and the ones using it for a few hours in a month. It is seen that the ones using internet for a few hours in a month have the highest mean in terms of means $(\bar{x}=314.99)$ and the ones using it for a few hours in a month have the lowest sensitivity $(\bar{x}=252.73)$. In this line, it can be said that the sensitivity of the 5 th classes.

Table 12. Kruskal Wallis Test internet use purpose

\begin{tabular}{|c|c|c|c|c|c|}
\hline Use Purpose & $\mathrm{n}$ & $\bar{x}$ & $\chi^{2}$ & $\mathrm{df}$ & $\mathrm{p}$ \\
\hline Information Purpose & 325 & 264.63 & 7.014 & 3 & .071 \\
\hline Social Purpose & 80 & 307.34 & & & \\
\hline Commercial Purpose & 12 & 310.63 & & & \\
\hline Fun & 141 & 295.34 & & & \\
\hline
\end{tabular}

According to Table 12, as a result of Kruskal Wallis-H performed to detect whether cyberbullying scale listing means have a significant difference according to the use frequency, no statistically significant difference was found $(\chi 2=7.014 ; \mathrm{df}=3 ; 05)$. Besides, it is seen that the internet is mostly used for the purpose information (research homework). 
Table 13. Mann-Whitney $U$ according to the use of Facebook

\begin{tabular}{|c|c|c|c|c|c|}
\hline & $\mathrm{n}$ & $\bar{x}_{\text {sira }}$ & $\sum_{\text {sira }}$ & $\mathrm{U}$ & $\mathrm{p}$ \\
\hline Yes & 337 & 272.15 & 90353.53 & 35075 & .334 \\
\hline No & 222 & 285.50 & 63381.50 & & \\
\hline
\end{tabular}

According to Table 13, there is no significant difference according to the use of Facebook by the students.

\section{Discussion}

In the research, more than half of the students have personal computer $(65.30 \%)$ and mobile phone $(50.98 \%)$ and internet will be used with the purpose of research and homework mostly $(58.14 \%)$, most of the students have Facebook account (59.39\%); their sensitivity relating cyberbullying is seen to be low with $\bar{x}=20.24$ point out of 42 points. Besides, it has been detected that the students use internet mostly with information purposes $(58.14 \%)$ and nearly half of them $(42.58 \%)$ use internet every day.

In the research performed with secondary school students by Baştürk-Akca, Sayımer \& Ergül [28], similar results were found and it has been detected that great majority of the students $(87 \%)$ have internet at their home and the primary use reason of the students is connecting to the social networks and $80 \%$ of the students visits social networks at least once a day and the most frequently used social network is Facebook (95\%). Besides, 24\% of the students $(n=48)$ were detected to be included in cyberbullying/victimization status. In a study made by Kocatürk, [29] and investigating peer and cyberbullying levels of secondary school students, it has been found that while $47.5 \% \mathrm{i}(\mathrm{n}=513)$ of the students were showing the tendency of cyberbullying, $54.8 \%(n=592)$ of them were exposed to the cyberbullying. In a study made by Çalışgan [30] with 632 eight grade students, it has been found that $39.22 \%$ of the students made cyberbullying and $40,38 \%$ of them are the victims of cyberbullier and of the main places where bullying is experienced, "Facebook" that is a social networking site comes first. In a study made by Çetinkaya [31] with 648 secondary school students, it has been detected that $63,1 \%$ of them have computers, the most important purpose of using internet by the students is doing homework $(35,1 \%)$ and the purpose of chatting follows this purpose at the same ratio $(35.1 \%)$, almost haldüf of the students $(48.2 \%)$ use internet more than a few hours a day; most of them $(44.6 \%)$ connect to the internet at their home and $(40.3 \%)$ of them have mobile phones.

In the study in which there is no significant difference in terms of gender variable, cyberbullying sensitivities of the girl students $(\bar{x}=20.60)$ and boy students $(\bar{x}=19.80)$ are close to each other. In the study related to the subject, it has been found to be different results. Erdur-Baker and Kavşut [22]; Arıcak et al. [32]; Çetinkaya [31]; Ayas \& Horzum [23]; Peker, Eroğlu \& Ada [33]; Çalışgan [30]; Şentürk \& Bayat [1] revealed that the boys make cyberbullying more than girls or they are tend to cyberbullying activities more than girls. Hinduja \& Patchin [34]; Yaman, Karakülah \& Dilmaç [35] have detected that the gender does not predict the bullying; Baştürk-Akca, Sayımer \& Ergül [28], have detected that there is no significant difference in terms of cyberbullying and gender.

In the study in which there are significant differences in terms of school type, it has been found that the lowest sensitivity belongs to School-7 $(\bar{x}=16.69)$ and School-5 $(\bar{x}=17.25)$ and the highest sensitivity belongs to School-1 $(\bar{x}=25.81)$. When the socio-economical level of the schools' surroundings and having personal computer by the students (School-7, $\bar{x}=76.92$ ) and internet use frequencies (School-7, $\bar{x}=35.90$ continuous and every day) are considered, the sensitivities of the students of the school in the vicinities having high socio-economic level were found to be low while the students studying in the schools in the vicinities having low income level or the schools having students who come to school by any transportation have higher cyberbullying sensitivities than the other schools since they use internet less.

In the research, it has been seen that the sensitivity related to the bullying is getting increased while the class level is getting increase; In other words the most important risk group was seen to be 5 th class. In the studies in literature the findings by contrast with the research findings were seen to be found. In the study examining the secondary school students' exposure to cyberbullying, Ayas \& Horzum [23] has found that there is no significant difference between class levels and cyberbullying but there is a significant difference in terms of making cyberbullying and cyberbullying amount increased with the increase in the class level. Kocatürk [29] also reached to the similar results in his study that he made with secondary school students and he has found that there is a significant difference between class level and cyberbullying and the students studying at the eighth grade class have a tendency of bullying more than the students studying at fifth and seventh grade students.

In the study, there is no significant difference in terms of having internet connected computer and mobile phone. That Çalışgan [30] did not find any statistically significant difference among the groups in terms of eight grade students' being the victim of cyberbullying and being cyberbulliers supports the research findings. Besides, in the study of Kocatürk [29] the cyberbullying tendencies of the students connected to the internet at home were found to be high, and it has also been found that the students connected to internet from the cafes were exposed to more bullying; the students having mobile phones show more cyberbullying tendency and they are exposed to more cyberbullying.

As a result, it is seen that the students' perception about safe internet use is low in Turkey. In Turkey where the internet has been carried to the education media with the important studies such as Fatih project in which internet has become an indispensable element, it is required to take 
subject related measurements and to make necessary studies about the safe use of the internet. In the coordination of London Economy and Policy Sciences School, in the research conducted simultaneously with 1000 children and their parents at the ages of 9 to 16 in 25 European countries between the years of 2009 and 2011 and named Europe Online Students Project [24], it has been found that the children and parents in Turkey have the lowest knowledge about safe internet use. The measures to be taken in line with this are submitted as follows;

a) Primarily, it can be trained staff to make awareness work for the students and their parents by organizing inservice trainings for the teachers.

b) Awareness studies (Poster, brochure, short film etc.) can be made in accordance with the school levels about the probable risks that gained more importance with Fatih Project realized in the primary school, secondary school and high schools.

c) Trainings can be organized to inform them about safe internet use.

d) In the training programs, the contents related to the courses such as information technologies or media literacy, subject related contents are added to the program and offered to the students.

\section{REFERENCES}

[1] Ş. Şentürk \& S. Bayat. High school students' opinions about internet use purposes and cyberbullying. ERPA International Congresses on Education 2015, 4-7 June 2015.

[2] Belsey, B. Cyberbullying. Retrieved February 7, 2015, from http://www.cyberbullying.ca, 2005.

[3] Ayas, T. \& Horzum, M.B.. Öğretmenlerin sanal zorbalık algılarının çeșitli değişkenlere göre incelenmesi. International Online Journal of Educational Sciences, 3(2), 619-640, 2011.

[4] Bayram N. \& Saylı M. Üniversite Öğrencileri Arasında Siber Zorbalık Davranıșı. Suç Önleme Sempozyumu, Bursa, 7-8 Ekim, 2011.

[5] N. Willard. The authority and responsibility of school officials in responding to cyberbullying. Journal of Adolescent Health, 41, 64-65, 2007.

[6] Q. Li. Bullying in the new playground: Research into cyberbullying and cyber victimisation. Australasian Journal of Educational Technology, Vol 23, Num 4, p. 445, 2007.

[7] H. Vandebosch \& C. Van Cleemput. Defining cyberbullying: A Qualitative research into the perceptions of youngsters, Cyberpsychology \& Behaviour, Vol 11, Num 4, p. 322, 2008.

[8] A. Nocentini, J. Calmaestra, A. Schultze-Krumbholz, H. Scheithauer, R. Ortega \& E. Menesini. Cyberbullying: Labels, behaviours and definition in three European countries. Australian Journal of Guidance \&Counseling, 20(2), 129-142, 2010.

[9] A. Peker. The effect of human values directionalphysco-education programon problematic internet use and cyberbullying. Unpublished Doctorate Thesis, Sakarya University Institute of Educational Sciences, Sakarya, 2013.

[10] P. Strom \& R. Strom. When teens turn cyberbullies. The Education Digest, 71 (4), 35-41, 2005.

[11] B. Belsey. Cyberbullying: A real and growing threat. ATA Magazine, 88(1), 14-21, 2007.

[12] N. Willard. Educator's guide to cyberbullying and cyberthreats. Retrieved from http://www.cyberbully.org/cyb erbully/docs/cbcteducator.pdf, 2005.

[13] J.W. Patchin \& S. Hinduja. Bullying beyond the schoolyard: Preventing and responding to cyberbullying. Thousand Oaks, CA: Corwin Press, 2012.

[14] S. Hinduja \& J. W. Patchin. Cyberbullying emotional and psychological consequences. Retrieved from http://www.cyberbullying.us/cyberbullying_emotional_cons equences.pdf, 2006.

[15] M. Şahin, S.V. Sarı, Ö. Özer \& S. Er. High school students' opinions about making cyberbullying behaviors and exposure to it.SDU Faculty of Science and Literature, Journal of Social Sciencess:21, pn.257-270, 2010.

[16] Hinduja, S. \& Patchin, J.W. „Cyberbullying: An Exploratory Analysis of Factors Related to Offending and Victimization."' Deviant Behavior, 29, 129-136, 2008.

[17] M. L. Ybarra. Linkages between depressive symptomatology and internet harassment among young regular internet users. Cyberpsychology and Behavior, 7(2), 247-257, 2004.

[18] S. Sharıff \& L.H. Dianne. Cyber bullying: Clarifying legal boundaries for school supervision in cyberspace. International Journal of Cyber Criminology. Volume: 1, Number: 1, $76-118,2007$.

[19] Mark, L.K. Student, educator, and parent perceptions of cyber bullying in three Hawai'i middle schools. Unpublished thesis. University of Hawai'i Educational Psychology, 2009.

[20] Santrock, J. W., Akranlar, Romantik İlişkiler ve Yaşam Tarzı."' (B. Uzun-Öner, Çev.). Editör D. M. Siyez, Ergenlik (pp. 204-329). Ankara:Nobel Yayınevi, 2012.

[21] Anderson, K. L. New kid on the block. Yükseklisans Tezi, California: California State University, 2012.

[22] Ö. Erdur-Baker \& F. Kavşut. New Aspect of Peer Bullying: Cyberbullying. Eurasian Journal of Educational Research, 27, pp, 31-42, 2007.

[23] Ayas, T. \& M. B. Horzum. Secondary School Students' being Cyberbullier and Victim status. Secondary School Online, 11(2), 369-380, http://ilkogretim-online.org.tr, 2012.

[24] EOSP. Europe Online Children Project Retrieved from $\mathrm{http}$ ://eukidsonline.metu.edu.tr/sites/default/files/image/duny a.jpg.2012.

[25] N. Karasar. Scientific Research Method, Nobel Publication Distribution, Ankara, 2009.

[26] A. Yıldırım \& H. Şimşek. Qualitative research methods in social sciences. Seçkin Publication, Ankara, 2005.

[27] T.Tanrıkulu, H. Kınay \& O.T. Arıcak. Sensitivity scale of cyberbullying İzmir: Book of XI. National Psychological 
Consultation and Consultancy Congress Notification Summaries p.338-339, 2011.

[28] E. Baştürk-Akca, İ. Sayımer \& S. Ergül. Secondary school students' social media use and cyberbullying experiences: Sample of Ankara, Global Media Journal TR Edition, 5 (10), Spring 2015.

[29] M. Kocatürk. The Investigation of the Relationship between Peer Bullying and Cyberbullying among Secondary School Students Unpublished Master Thesis. İstanbul University. Department of Educational Sciences. İstanbul, 2014.

[30] H. Çalıșgan. Internet addiction of Secondary School students and cyberbullying Unpublished Master Thesis. Yeditepe University Social Sciences Institute, Department of Education Management and Inspection. İstanbul, 2013.

[31] B. Cetinkaya. The prevalence of cyberbullying among secondary school. Unpublished Master Thesis.Selçuk University, Institution of Education Sciences. Konya, 2010.
[32] T. O. Arıcak, S.Siyahhan, A. Uzunhasanoğlu, S. Sarıbeyoğlu, S. Çıplak,N. Yılmaz, N. et al. Cyberbullying among Turkish adolescents. Cyberpsychology and Behavior, 11(3), 253-261, 2008.

[33] A.Peker, Y. Eroğlu \& Ş. Ada. The investigation of the predictors of cyberbullying and victimization in the adolescents. Abantİzzet Baysal University, Journal of Faculty of Education [S.1.], dec. 2012.http://www.efdergi.ibu.edu.tr/i ndex.php/efdergi/article/view/913>, 2012.

[34] S. Hinduja, \& J.W. Patchin. Bullying beyond the schoolyard: Preventing and responding to cyberbullying. California: Carwin Pres, 2009.

[35] E. Yaman, D. Karakülah \& B. Dilmaç. To important variables predicting secondary school students' values: The relationship between cyberbullying tendencies and school culture. Journal of Values Education, Volume 11, No. 26, 323-337, 2013. 